\title{
Toward a State-Wide Newspaper Microfilming Program
}

Dr. Eaton is associate director, Louisiana State University Library.

This IS A CASE STUDY of the problem of film. It has a three-fold purpose: (I) to describe what has already been done in the way of filming Louisiana papers, (2) to outline what remains to be done, and (3) to suggest a cooperative program in which Louisiana libraries can pool their efforts to complete the job. It is presented with the hope that it may be of use to librarians contemplating state-wide newspaper filming programs, both as a warning of some of the difficulties involved and as a description of procedures developed through trial and error in one state.

The deterioration of newspaper files presents an urgent problem for librarians, publishers and scholars throughout the country. Unless systematic action can be taken on a large scale in the near future, a large body of valuable source material will be irreparably lost. The seriousness of the matter is attested by the fact that the recently appointed ALA Committee on Cooperative Microfilm Projects has decided to give first priority to the preservation of American newspapers. This Committee has begun by sponsoring a nation-wide survey of existing newspaper files. With the results of this survey in hand, the Committee will attempt to encourage the microfilming of papers in all forty-eight states.

Although the work of the Committee on Cooperative Microfilm Projects represents one of the first attempts to cope with the problem on a nation-wide basis, there have been numerous efforts on a smaller scale to preserve newspapers. Several types of agency have participated in these activities: individual libraries, state historical societies, state library associations, commercial firms, individual publishers, and learned societies. Among libraries, the Library of Congress, the New York Public Library and the University of Chicago Library, for example, have filmed considerable papers from all parts of the country. The Wisconsin State Historical Society has been especially active in filming current $W$ isconsin papers. At the present time this institution is filming over 300 weeklies and about 35 dailies published in the state, as well as 250 labor and trade union papers from all parts of the country. The Missouri and Kansas State Historical Societies also have been carrying on ambitious programs of newspaper preservation, the Missouri Society having been engaged in the work since 1937. The California Library Association, through an active Committee on the Conservation of Newspaper Resources, has made considerable progress in developing a state-wide plan for newspaper preservation, and has attempted with some success to coordinate the efforts of a number of large libraries with active filming programs. Among commercial firms the Recordak Corporation, a subsidiary of Eastman Kodak, is probably the largest and best-known producer of newspaper microfilm. Individual publishers have in some instances gone in to the microfilming business 
on their own, thinking apparently that they could do the job for themselves at less cost. The New Orleans Times-Picayune project is an example of this type of filming venture. Among learned societies the American Council of Learned Societies has pioneered in the newspaper field by sponsoring the filming of Negro papers on a nation-wide scale. The actual filming in this instance was done by the Library of Congress.

\section{The Problem}

The newspaper problem confronting Louisiana librarians may be summed up in a few simple propositions:

I. Newspapers are a valuable source of information for the study of local and state history. As such they should be preserved and made available to present and future investigators.

2. Of the hundreds of different papers published in Louisiana since I 794 when the Moniteur de la Louisiane first appeared in New Orleans relatively few survive in complete or nearly complete files today. The number of papers lost or destroyed is so large as to be almost unbelievable.

3. Of the papers which have been preserved, a large number, particularly those published since about 1870 , are on wood pulp paper. This paper yellows and crumbles when exposed to light and air. In time it disintegrates to the point where it can scarcely be used.

4. A good many of the papers still in existence are located in publishers' offices, parish court houses and in private homes and offices. Most of these files are inadequately housed and subject to destruction by fire, insects and general neglect. Even where they are well cared for they are often inaccessible to scholars and other people who want to use them.

5. Of the newspaper files which survive, whether on wood pulp or some more durable type of paper, many are scattered in two or more locations, both within the state and outside, so that readers are frequently inconvenienced and impeded in their use of the papers.

There are various good reasons to explain why newspapers are difficult to preserve and why so few of them have survived. Of primary importance is the factor mentioned above, the perishability of the wood pulp paper. This applies to papers in libraries as well as to those which are less adequately housed. Regardless of the care which is given them, these files deteriorate steadily unless they are stored in darkened vaults under strict temperature and humidity controls and unless they remain unused. Another factor is the form of the papers. Because they are bulky they are difficult to store and expensive to bind. Unbound and inadequately housed, they are an easy prey for insects and other destructive agents. A third explanation is the lack of appreciation of the value of old newspapers. It is only within the last seventy years that scholars themselves have used newspapers as source materials. To the layman a newspaper is a common article of no monetary or other worth except perhaps as waste paper. With a few exceptions even publishers have been lacking in appreciation of the value of newspapers. Some of them have used their own files of the past decade or two for the purpose of weekly "looking backward" columns, but even this immediate utility has in many cases been insufficient to persuade them to bind and preserve their papers.

In the absence of any accurate figures on newspaper production in Louisiana, one may hazard a conservative guess that there have been perhaps 850 different papers published in the state during the past century and a half. The most comprehensive list, which is incomplete, contains about 800 titles. Edward L. Tinker's Bibliography of the 
French Newspapers and Periodicals of Louisiana ( I933) lists 22 I French papers alone. According to Tinker, these publications "sprang up in Louisiana like mushrooms and died like flies during the nineteenth century." Of the 850 titles, no more than a handful have been preserved in complete form, and not more than a fourth survive in substantial runs.

\section{Microfilm as a Solution}

The development of microphotography within the past fifteen years has opened up new possibilities in acquiring and preserving newspapers. As a solution of the problems posed by newspaper files, microfilm offers several advantages: ( I ) It provides a means for the permanent preservation of papers which would otherwise deteriorate or be destroyed. (According to government tests, film can be expected to last at least as long as the best rag paper.) (2) It offers the possibility of bringing together papers which are scattered in two or more locations, so that there is on microfilm a more complete file than is available anywhere in the original. (3) It makes papers more readily available to users by providing copies where the originals are not conveniently accessible. A publisher in North Louisiana, for example, may possess the only existing file of his paper. By means of film, a copy of this file can be provided for users in Baton Rouge or New Orleans. (4) It makes possible a considerable saving of space in the storage of newspaper files. A small roll of film can be housed in a fraction (about $2 \%$ ) of the space required to accommodate bound newspapers.

A good beginning has already been made in the preservation of Louisiana newspapers on film. Some papers have been filmed by the Recordak Corporation, some by the publishers themselves, some by the Library of Congress and some by the Louisiana State University Library.
According to information received from the company, Recordak is now filming two Louisiana papers: the Shreveport Journal and the Shreveport Times. The publisher has borne the expense of filming in both cases. Positive copies of the film can be obtained from the Recordak Corporation through the publisher.

At least one Louisiana publisher has undertaken his own filming project. Several years ago the Times-Picayune, a New Orleans daily paper, began the ambitious project of filming its back files from 1837 to date. The work has progressed without serious interruption, and will eventually be completed. (The years I837-I9I7 have been finished as of February, 1952.) Positive copies of this film will be available for purchase. Even before the back file was completed, recent volumes (beginning in January, I95I) were filmed and offered to subscribers.

The Library of Congress has filmed two groups of Louisiana papers, the first consisting of early Alexandria and St. Francisville papers in its own collections, filmed at the request of the L. S. U. Library, and the second comprising five New Orleans papers which were filmed as a part of the Negro Newspaper Microfilming Project under the sponsorship of the American Council of Learned Societies.

The Louisiana State University Library began its program of newspaper microfilming four years ago with the opening of its new Microfilm Department. From the very beginning this program has been a major part of the Department's work. The program was undertaken as a completely non-profit venture for the purpose of preserving papers and of making them available to users. During the four years of its operation the Department has produced more than a thousand rolls of newspaper film, representing about 50 different papers. The work has been carried on in addition to 
the filming of books, journals and manuscript material in response to requests from both L. S. U. students and faculty and from libraries and industrial firms throughout the state and region.

The newspaper files filmed under the L. S. U. program include titles published in 30 different cities and towns in the state. Almost all sections are represented, from Benton, Bastrop and Lake Providence in the north to Abbeville, St. Martinville and Thibodaux in the south. The first papers filmed were the Baton Rouge dailies (the State Times and the Morning Advocate), which were done with the cooperation and financial assistance of the publisher. Another paper filmed early in the program was the American Progress, the political organ of the Huey Long organization during the I930's. Some of the titles filmed, such as the Louisiana Democrat (Alexandria) and the Bossier Banner (Benton), date from the ante-bellum period. Beginning in the late I860's or I 870 's there are good files of such papers as the Iberville South (Plaquemine), the Thibodaux Sentinel, the Colfax Chronicle, the Assumption Pioneer (Napoleonville), the Tensas Gazette (St. Joseph), the Abbeville Meridional, and the St. Tammany Farmer (Covington). For the I880's there are the Morehouse Clarion (Bastrop), the Teche News (St. Martinville), the Madison Journal (Tallulah), the Lafourche Comet (Thibodaux) and the Banner Democrat (Lake Providence). The I 89o's are represented by such papers as the Era Leader (Franklinton), the Clarion News (Opelousas), and the St. Francisville Democrat. Approximately half of the titles filmed began publication after $\mathbf{I} 900$.

\section{Procedures}

A brief account of the procedures followed in the L. S. U. microfilming program will illustrate some of the problems in- volved. The first problem was to find out what papers are still in existence. Fortunately, there are several guides to newspaper resources in the state: (I) the best of these is the so-called "WPA List" or, more correctly, Louisiana Newspapers, I7941940: a Union List of Louisiana Newspaper Files Available in Offices of Publishers, Libraries, and Private Collections in Louisiana (prepared by the Louisiana Historical Records Survey, Division of Community Service Programs, Work Projects Administration, and issued in mimeographed form by the L. S. U. Library, October, I94I) which, though incomplete and to some extent inaccurate, is a mine of information about Louisiana newspapers and the location of existing files; (2) E. L. Tinker's Bibliography of the French Newspapers and Periodicals of Louisiana (Worcester, American Antiquarian Society, I933), a pioneer work which locates files of many of the papers included; (3) American Newspapers, I82I-I936; a Union List of Files Available in the United States and Canada (edited by Winifred Gregory under the auspices of the Bibliographical Society of America, 1937) has been useful for the location of issues of Louisiana papers in libraries outside the state; and (4) Newspaper Files in Louisiana State University Library, a mimeographed list prepared by the Library in 1947 , contains detailed information about L. S. U. holdings, much of which is not in the WPA List. In addition to these published lists we have had access to more recent information about publishers' files and library holdings, assembled through correspondence by two Louisiana Library Association Committees.

Valuable as these sources have been, they have had to be supplemented by correspondence with librarians and publishers and by field trips. Actual visits to publishers' offices, court houses and the residences of individual owners of newspaper files are 
often the only satisfactory way of determining what papers are available.

After surveying the available information regarding existing files of newspapers, we next faced the problem of where to begin. At this point the decision was made to concentrate first on files located outside libraries. This decision was based on the fact that newspapers housed in publishers: offices, parish court houses, private homes and places of business are, as a rule, inadequately cared for. We knew that many of them had already disappeared. By giving them first priority we hoped that we might thereby preserve some which would otherwise be destroyed.

The next problem was to obtain the papers which we had decided to film. This meant bringing the files to the L. S. U. campus where they could be filmed on a large stationary camera especially designed for newspaper work. For this purpose the cooperation of the publishers had to be obtained, and this proved in many cases to be no easy task in spite of the fact that, for weekly papers at least, there was no financial or other obligation on their part. While some publishers were responsive and eager to cooperate, many of them displayed little or no interest, even to the point of ignoring correspondence completely. Some of them undoubtedly knew nothing about microfilm. and could make no sense whatever of proposals relating to it. Others understood the purpose of filming, but could see no practical advantage to themselves in participating in such a project. A few valued their files so highly that they were reluctant either to lend them or to run the risk of having them damaged in the filming process. One publisher was so proud of his unique files of several early papers that he would not permit filming because others would thereby obtain copies. Another was interested in selling a duplicate fifty-year file of his paper and felt that filming would spoil his chances of finding a customer. In one unique instance, the owner of certain older papers happens to be a company which makes a business of searching land titles. This company is located in a parish whose court house was destroyed by fire forty-two years ago. The only records surviving are in the possession of this company, and these include the succession and probate records printed in the local newspapers. These records have an extremely high monetary value to the company for the simple reason that there are no duplicates. To permit filming them would be to run the risk of throwing away this advantage. For this reason, these newspapers will probably never be made available to the public. The loss is a serious one, which is mitigated only by the knowledge that the papers will be very carefully preserved.

Transportation proved to be another problem involved in obtaining papers. In most cases publishers, even when they wanted their files filmed, were not sufficiently interested either to bring their papers to the Library or to pack them for shipment. This meant that the Library usually had to assume responsibility for transportation both ways.

Having been brought to the Library, the papers next had to be prepared for filming. The collation of the files involved page-bypage examination to detect missing issues, errors in dating or page numbering, and torn or damaged pages. All these imperfections were carefully marked for the attention of the camera operator. Torn pages were mended, and a record of missing issues was prepared. This job requires painstaking accuracy and attention to detail, and it has consumed considerable time on the part of L. S. U.'s Newspaper Librarian.

When the file had been collated, the next step was to locate missing issues. This was done by writing to the publisher and to other libraries which, according to the published 
guides, are supposed to have issues. Publishers have been able occasionally to supply missing papers either from their own files or from individuals in the community. Other libraries have been extremely cooperative in supplying issues needed to fill gaps. The assistance received in this way from the $\mathrm{Tu}$ lane University Library, the Louisiana State Library and the Louisiana State Museum has been especially valuable. Libraries outside Louisiana have also cooperated in supplying microfilm copies of scattered issues in their possession. In the case of one of the Baton Rouge papers, issues were obtained from seven different libraries including three outside the state. This kind of library cooperation is essential to the success of any filming program.

\section{Papers Yet To Be Filmed}

What other papers should be filmed? With respect to back files, perhaps the chief criterion is availability. We shall probably want to film most of the files which have been preserved. A survey made recently for the Committee on Cooperative Microfilm Projects provides a list of papers for the period since 1870 . This list contains about I 50 titles, which run to approximately $3 \frac{1}{2}$ million pages. If the L. S. U. Library were to film these papers, the job would take about thirteen years.

Then, there are the older papers published prior to I 870 and of which there are no files surviving beyond that date. No study has been made of the number of these files still in existence. They are listed in the WPA List, of course, and also in Gregory's American Newspapers, 1821 1936. Most of them are New Orleans papers which have been preserved in the Archives of the New Orleans Public Library and in the Louisiana State Museum. The number of these files located outside libraries is relatively small.

What about current papers? We know that about 130 of them are now being published in the state. One solution might be to film all of them. This comprehensive coverage is apparently being achieved in Wisconsin where there are more than 300 papers issued currently. For Louisiana a selective policy seems more realistic, however, from the standpoint. both of financing the program and of the value of the papers. Under such a policy the principal criteria of selection might be (I) geographical location and (2) the importance of the papers. There should probably be at least one paper filmed from each of the state's 64 parishes. Beyond this the factor of "importance" could be decisive, as indicated by such matters as ( 1 ) circulation, (2) prestige in the community, (3) value as a record of the official business of the parish (some papers are designated as "official journals" of parishes, school boards, levee boards and other governmental agencies), (4) value as a mirror of community life and opinion, and (5) journalistic excellence. Additional factors which might be considered are the availability and extent of the back file. Other things being equal, it would probably be preferable to select a current paper whose back file is extensive and is already on film than one which has been established recently.

Justification for filming current papers is not difficult, particularly in the light of experience with back files. To the investigators of the future, present-day papers will doubtless be as important and useful as a guide to local happenings and opinions as the newspapers of the I850's are to scholars of the present day. If these current papers can be preserved ncw while they are readily available and in good condition, many of the difficulties now being encountered in the filming of older papers will be obviated. Microfilming on a current basis means that the job will be done once and for all, with a minimum of effort and expense. 
What factors should determine priority of filming, once the list of available or preferred papers is compiled? As between current papers and older files, the latter should undoubtedly be filmed first even though this means deferring a program for current issues. This has been done at L. S. U. A beginning has been made on the current papers, however, by filming the latest years of those titles whose back files have been filmed. The volume of such current papers has not been sufficient to interfere with the work on the back files, and the problem of publisher cooperation has already been solved for these titles.

In deciding on a priority list for older papers there are several factors to consider: (I) type of newsprint (wood pulp or rag), (2) location of the files, (3) importance of the papers, and (4) condition of the files. In general, it is the wood pulp papers of the period 1870 to date which deserve first attention because of their perishability. Almost equally important, however, is the matter of location. Files in publishers' offices and in private hands, whether on wood pulp paper or not, should be filmed without delay if they are to be preserved. The importance of papers for research is another factor to take into account. Generally speaking, present-day historians are more interested in early papers (i.e., prior to I880) than in those published later. And they are more interested in some parts of the state than in others. These preferences on the part of scholars have been determined, and they will be useful in the assignment of priorities. A final consideration may be the condition of back files. If a paper is on the verge of complete disintegration, it should obviously be filmed even though it is neither in a publisher's office nor among the first group of titles in importance for research. The Lake Providence papers in the L. S. U. Library are an example of files which were filmed simply because of their poor condition.
The assignment of priorities, even when based on the above factors, involves arbitrary decisions and a good deal of guess work. Furthermore, the priorities must always be subject to revision as the factor of availability enters in. The files which look most promising in the published guides may turn out upon closer investigation to be either nonexistent or available only after prolonged negotiation and delay.

\section{Sources of Funds for \\ Financing Filming Projects}

Although perhaps less expensive than other methods of preserving newspapers, microfilming costs money. The initial expense of setting up a Microfilm Department, including the cost of a special camera and processing equipment, is considerable. Skilled personnel to operate the Department represents a substantial outlay. And to these must be added the cost of the film itself and the expense of transportation, to mention only the most obvious items.

Who is going to pay the bill for a statewide program of newspaper preservation? There appear to be two possible sources of funds for financing microfilming projects: ( I) libraries and publishers in the state and (2) philanthropic foundations interested in supporting broad educational and cultural programs.

Libraries and publishers in the state bear the major responsibility for preserving local newspapers. By pooling their efforts in a planned cooperative program, they will be able to achieve substantial results within the next few years. Such a cooperative program, based on a division of responsibility among interested libraries and publishers, might operate along the following lines:

I. Parish weeklies

In its own filming activities thus far the L. S. U. Library has concentrated chiefly on the back files of "parish" weekliesi.e., weekly papers published outside New 
Orleans. As indicated above, this decision was based on the urgent need for action to preserve these papers. The cost of filming these files and of purchasing positive copies where necessary has been borne almost entirely from the $\mathrm{Li}$ brary's funds. Many of these files remain to be filmed, and L. S. U. intends to continue its emphasis on this type of paper.

2. New Orleans papers

Like L. S. U., the large libraries of New Orleans have a two-fold interest in newspaper filming. To them it offers a solution of the problem of preserving valuable collections, and it makes possible greater accessibility of materials needed by the users of these libraries. It would seem logical that the Tulane University Library, the New Orleans Public Library, the Louisiana State Museum and perhaps other institutions should assume responsibility for filming some of the older New Orleans papers in their own collections. This would represent a division of responsibility based on both interest and present holdings.

3. Parish dailies

With New Orleans papers and the parish weeklies taken care of, there remains the problem of daily papers published in some of the smaller cities, e.g., Alexandria, Crowley, Lafayette, Monroe, New Iberia, Opelousas, Ruston. Being parish papers, these files fall within the field of L. S. U.'s interest. Because they are daily papers, however, the cost of filming extensive back files is usually too great for one institution to bear alone. These papers appear to offer an excellent opportunity for cooperative projects on the part of local public and college libraries and publishers. Since they are all interested in preserving local papers and in having access to back files, they should be able to agree on a division of the cost which would not overburden any of them. It is hoped that the libraries in one or two of the cities mentioned may be willing to explore the possibilities of this kind of cooperative arrangement in the near future.

It may be that financial support for newspaper filming can be secured from one or more foundations. This, at any rate, is the hope of the Committee on Cooperative Microfilm Projects. Such foundation support as can be obtained for Louisiana should probably be devoted to the filming of older New Orleans papers and of some of the parish dailies. So many titles have been published in New Orleans and the extant files are so extensive that some outside assistance will undoubtedly be necessary to finance an adequate filming program for these papers. The possibility of foundation aid should not deter Louisiana libraries, however, from going ahead to the limit of their present resources. The fact that there is an active program in the state with solid accomplishments behind it and a welldefined plan for future operation should greatly strengthen any request for foundation assistance which may be made in the future.

\section{Availability of Films}

The question of how microfilm copies of Louisiana newspapers can be made available to users is one which naturally concerns libraries both within and outside the state. Once the papers are copied, what will become of the film? Will readers have to go to L. S. U. or to some New Orleans library to use it? Or will there be positive copies of the film for use in other parts of the state? Or can the film be borrowed on inter-library loan to meet specific requests?

These are difficult questions, and no easy answers to them can be given here. Libraries have had little or no experience in lend- 
ing microfilm, and it is too early to say what practices will become accepted. In place of definite answers, the following observations may be pertinent:

x. Positive copies of newspaper files can easily be made from negative film. For a paper that is used frequently, positive copies in two or more locations are probably justifiable.

2. Positive copies of extensive files, however, are fairly expensive. For infrequent use some other alternative may be preferable. If libraries spend their funds lavishly for extra copies, there will be less money available for making negative films of papers which should be preserved. The indications are that many libraries are willing to adopt generous lending policies, even to the extent of lending negative film. The fact that film is easily damaged will make it necessary for lending libraries to insist that their film be used only on high-grade reading machines and under strict supervision.

3. A policy of liberal lending of microfilm is an essential part of a cooperative newspaper filming program in which many libraries share the cost of producing the negative film.

\section{The ACRL Buildings Committee}

(Successor to the Cooperative Committee on Library Building Plans)

\section{Presents the Proceedings of the LIBRARY BUILDING PLANS INSTITUTE}

which it sponsored at OHIO STATE UNIVERSITY in APRIL I952

Detailed analysis and criticism by librarians and architects of plans and specifications for seven college and university library buildings ranging in capacity from I00,000 volumes and 350 readers to more than $1,000,000$ volumes and 3500 readers. Special attention given to requirements and implications of modular design.

Eighty pages, including thirty pages of plans. Edited by David Jolly, Assistant Librarian, Northwestern University. Published as ACRL Monograph No. 4. Price \$I.75. Place a standing order to receive all ACRL Monographs automatically as published, and be billed later. Or order No. 4 separately (cost of Nos. I-3, \$I.Io; with No. 4, \$2.85). Address all orders to:

Business Manager, ACRL Monographs

c/o University of Illinois Library

Chicago Undergraduate Division

Chicago I I, Illinois

\section{Hercules and Antaeus}

(Continued from page 25)

studies of the past must be organically linked with an understanding of our immediate and most pressing problem, current bibliographical control.

There can be no doubt that most librarians are vitally interested in books and are painfully aware of their lack in book knowledge. Many recent experiences have shown that the library staff responded en- thusiastically to every opportunity to broaden their knowledge. It is the duty of all of us to make this interest active. In preparing work schedules, in fostering continuous in-service training, in preferment and promotions within the library, book knowledge should be considered an important factor. The entire profession must be conscious at all times that the first half of librarianship is Liber. 